\title{
The Effect of Anti TNF-Alpha Therapy in Nutritional Status and Serum Leptin Levels in Patients with Ankylosing Spondylitis
}

\author{
Kadayifci Fatma Zehra ${ }^{1,2, *}$, Gezmen Karadag Makbule ${ }^{1}$, Onat Ahmet Mesut ${ }^{3}$ \\ ${ }^{1}$ Department of Nutrition and Dietetic, Gazi University, Ankara, Turkey \\ ${ }^{2}$ Department of Health Sciences, California Baptist University, Riverside-CA, USA \\ ${ }^{3}$ Departments of Rheumatology, Gaziantep University, Gaziantep, Turkey \\ *Corresponding author: fzkadayifci@gmail.com
}

\begin{abstract}
The objective of this study was to investigate the effect of anti TNF- $\alpha$ therapy on nutritional status and serum leptin levels in patients with ankylosing spondylitis. This study was conducted on two groups of AS patients. First group included 48 patients receiving anti TNF- $\alpha$ treatment together with NSAID. Second group included 48 patients receiving only NSAID treatment. Descriptive information, food consumption and physical activity about patients collected with a survey. Anthropometric measurements were measured with body analysis scale and serum leptin was also assessed. As results, there was significant difference in daily energy consumption between both men and women with and without anti TNF- $\alpha$ treatment (2399 kcal and $2069 \mathrm{kcal}$ p=0,036, $2102 \mathrm{kcal}$ and $1659 \mathrm{kcal}$ $\mathrm{p}=0,001)$. There was no significant difference of serum leptin levels between patients receiving anti TNF- $\alpha$ and only NSAID treatment $(p>0,05)$. However, the women's leptin levels $(12,4 \pm 8,2 \mathrm{ng} / \mathrm{mL})$ were significantly higher compared to men $(3,7 \pm 3,02 \mathrm{ng} / \mathrm{mL})$. There was positive correlation of serum leptin levels, BMI and body fat mass between men and women with and without anti TNF- $\alpha$ treatment. The anthropometric measurements between both men and women groups were not significant $(\mathrm{p}>0,05)$. No statistical difference was found between the physical activity assessments of the groups ( $\mathrm{p}>0,05)$. In conclusion, there was no significant effect of anti-TNF- $\alpha$ treatment in AS patients on serum leptin levels, physical activity, and anthropometric measurements. However, anti TNF- $\alpha$ therapy receiving patients' daily energy and nutrient consumption were higher. This study showed anti TNF- $\alpha$ therapy has been effective on food consumption of patients with ankylosing spondylitis.
\end{abstract}

Keywords: anti TNF- $\alpha$, ankylosing spondylitis, nutrition, serum leptin

Cite This Article: Kadayifci Fatma Zehra, Gezmen Karadag Makbule, and Onat Ahmet Mesut, "The Effect of Anti TNF-Alpha Therapy in Nutritional Status and Serum Leptin Levels in Patients with Ankylosing Spondylitis.” International Journal of Clinical Nutrition, vol. 5, no. 1 (2017): 8-12. doi: 10.12691/ijcn-5-1-2.

\section{Introduction}

Ankylosing spondylitis (AS) is a chronic inflammatory rheumatologic disease, which considered as one of the subtype of spondylarthritis [1]. Treatment in AS includes patients' education, exercises, nonsteroid anti-inflammatory drugs (NSAIDs) and in recent years anti tumour necrosis factor-alpha (anti TNF- $\alpha$ ) therapy [2]. TNF- $\alpha$ play a significant part in the pathogenesis of AS and increased expression of TNF- $\alpha$ is associated with inflammation [3]. Anti TNF- $\alpha$ treatment, which can modify the disease's course by controlling inflammation in the joints, is used in the mid and the late phase of rheumatologic patients [4].

Leptin is an adipose tissue hormone, which is the basic regulator of food behaviour and energy homeostasis [5]. Leptin also plays a significant role in endocrine and immune functions [6]. It has been shown that leptin has pro-inflammatory properties and associated with the secretion of several inflammatory cytokines, especially TNF- $\alpha$ [7]. On the contrary, TNF- $\alpha$ and Interleukin 1B
(IL-1B) stimulates the increase of serum leptin levels and leptin mRNA expression in fat during acute infections. Therefore, it may decrease lean body mass [8]. Pro-inflammatory signalling in the hypothalamus, mostly promoted by TNF- $\alpha$ may play a dual role in the control of feeding and thermogenesis in some cases promoting catabolism and in the other cases causing obesity [9].

In an animal study administration of anti TNF- $\alpha$ antibody significantly reduced serum leptin levels and before the treatment it's determined that mice consumed less food and lost weight [10]. A plot human study showed that TNF- $\alpha$ could control leptin levels [11]. Thus, one would expect lowering of serum leptin levels during anti TNF- $\alpha$ therapy might affect food intake and nutritional status. This relationship wasn't shown in a human study.

The aim of this study was to evaluate whether anti TNF- $\alpha$ therapy effects nutritional status and serum leptin levels of the AS patients. It is expected to show that anti TNF- $\alpha$ therapy may lead to a wider perspective of the efficacy in AS and may provide original contribution to the literature. 


\section{Materials and Methods}

This is a prospective, controlled clinical trial including AS patients receiving anti TNF- $\alpha$ or NSAID treatment. The study protocol was reviewed and approved by the Ethics Committee. Written informed consent was obtained from all patients.

\subsection{Patients}

AS patients, diagnosed with BASDAI criteria and under follow up by Gaziantep University Hospital Rheumatology Clinic were included in the study. The first group consisted of patients receiving anti TNF- $\alpha$ therapy for at least 3 months and the second group consisted of patients receiving only NSAID treatment. Each group included 48 patients with similar age, gender and BMI distribution (Table 1). Exclusion criteria were as follows: patients with chronic diseases other than AS, patients treated with steroid containing drugs, immunosuppressant and pregnant women.

\subsection{General and Dietary Assessments}

Nutrition specialist collected the research data during patient interviews with a survey. Survey included personal information, physical activity status, and nutrition records. Anthropometric measurements were taken and biochemical parameters were analysed.

Participants diet was assessed with 24-hour dietary recall. In order to record food and portion sizes properly 'Food and Nutrition Photo Catalogue' was used [12]. Average energy and nutritional value of food consumed was calculated using Nutrition Information System Software (BeBis Inc., Istanbul, TURKEY) [13]. The calculated amount of energy and nutrients evaluated according to the Nutrition Guide for Turkey 2015 (TUBER, 2015) reference range [14].

\subsection{Anthropometric Measurements}

Registered dietician took all measurements with patients wearing light clothes and no shoes. Body weight (kg), body height (cm), waist and hip circumferences (cm) were measured using standard measurement protocols $[15,16]$. BMI was calculated as body weight $(\mathrm{kg})$ divided by body height squared $\left(\mathrm{m}^{2}\right)$. Waist-hip ratio was calculated by dividing waist circumference to hip circumference. Measurements compared using World Health Organization (WHO) classification [16].

Body fat mass (\%), total body water (\%), lean body mass (\%), estimated bone mass $(\mathrm{kg})$ were measured with Tanita BC 532 body analysis scale. Before the Tanita measurement, individuals have been asked not to do heavy physical activity within 24-h, and not to consume much liquid (water, tea, or coffee) and had at least 4 hours of fasting.

\subsection{Physical Activity Assessment}

To determine participants' physical activity levels, the International Physical Activity Questionnaire Short Version (IPAQ-SF) was used. With IPAQ-SF the type of activity and weekly activity time has questioned. The values obtained using the IPAQ-SF Guide [17].

\subsection{Biochemical Measurements}

Blood samples were collected, centrifuged and serum samples were removed and stored at $-70^{\circ} \mathrm{C}$ until the day of examination. Serum leptin levels $(\mathrm{ng} / \mathrm{ml})$ were measured using Leptin (Sandwich) ELISA kits (DRG, Germany). Serum leptin have been studied in 82 of 96 patients because of technical problems.

\subsection{Statistical Analyses}

The power analysis wasn't calculated due to a lack of similar studies. Data analysis was carried out using SPSS version 15.0 software (SPSS Inc., Chicago, IL, USA). Results were expressed as means $(\bar{x})$ and standard deviation (SD) for the data. Independent t test was used to assess the comparison of values between the two groups. Pearson correlation coefficient (r) test was conducted to examine the relationship of leptin and body composition. Significance is defined as a p-value less than 0,05.

Table 1. Demographic and clinical features

\begin{tabular}{lcc}
\hline & Anti-TNF (+) & Anti-TNF (-) \\
\hline Patients (n) & 48 & $25 / 23$ \\
Sex, male/female (n) & & $24 / 24$ \\
Education & $14(29,2)$ & $13(27,1)$ \\
$\quad$ Primary, n (\%) & $26(54,2)$ & $19(39,6)$ \\
High School, n (\%) & $8(16,6)$ & $16(33,3)$ \\
University, n (\%) & $6,5(3-15)$ & $5,6(1-12)$ \\
Mean disease duration, years (min-max) & $5.1(1,22)$ & $5,3(1,70)$ \\
BASDAI*, mean (SD) & 63,6 & 55,4 \\
HLA-B27 + (\%) & & - \\
Anti TNF- drugs & $11(22,9)$ \\
Etarnercept, n (\%) & $12(25,0)$ \\
Adalimumab, n (\%) & $17(35,4)$ \\
Golimumab, n (\%) & $8(16,7)$ \\
\hline Infliximab, n (\%)
\end{tabular}

*BASDAI, Bath Ankylosing Spondylitis Disease Activity Index (0-10, 10=worst). 


\section{Results}

\subsection{Measures of Body Composition}

As shown in Table 2, there hadn't been found any significant difference in mean body weight, BMI, waist/hip ratio and several body compositions between both gender and group $(\mathrm{p}>0,005)$. However mean BMI of all participants were above the normal range $\left(>25.0 \mathrm{~kg} / \mathrm{m}^{2}\right)$.

\subsection{Daily Average Nutrient Consumption and Physical Activity}

It has been found that both men and women receiving treatment with anti TNF- $\alpha$ had significantly higher energy, fibre and monounsaturated fatty acid consumption $(\mathrm{p}<0,005)$. Moreover, women receiving treatment with anti TNF- $\alpha$ had considerably higher saturated fat, total fat (g), and total carbohydrate (CHO, g) consumption (Table 3). No statistical difference was found between the physical activity assessments of the groups ( $p>0,05)$.

\subsection{Serum Leptin Analyses}

The serum leptin levels were tested in 41 patients from each group. No significant differences in serum leptin levels were found between the groups (7.5 $\pm 6,35$ vs. 8,6 $\pm 8,69$, $\mathrm{p}=0,533)$. Overall leptin levels were significantly higher in 41 female patients compared to 41 men $(12,4 \pm 8,22$ vs. $3,7 \pm 3,08, p=0,001)$. There were significant and positive correlation between serum leptin, BMI, and body fat mass (\%) in both groups $(\mathrm{p}<0,005)$ (Table 4). A negative correlation between serum leptin levels, lean body mass (\%), total body water (\%) and estimated bone mass were significant in both groups $(\mathrm{p}<0,005)$.

Table 2. Mean age and anthropometric measurements

\begin{tabular}{|c|c|c|c|c|c|c|c|c|c|c|}
\hline & \multicolumn{4}{|c|}{ Anti-TNF (+) } & \multicolumn{4}{|c|}{ Anti-TNF (-) } & \multirow[b]{3}{*}{$\mathbf{p}^{1}$} & \multirow[b]{3}{*}{$\mathbf{p}^{2}$} \\
\hline & \multicolumn{2}{|c|}{ Men (n: 25) } & \multicolumn{2}{|c|}{ Women (n: 23) } & \multicolumn{2}{|c|}{ Men (n: 24) } & \multicolumn{2}{|c|}{ Women (n: 24) } & & \\
\hline & $\bar{x} \pm \mathrm{SD}$ & Min-Max & $\bar{x} \pm \mathrm{SD}$ & Min-Max & $\bar{X} \pm \mathrm{SD}$ & Min-Max & $\bar{X} \pm \mathrm{SD}$ & Min-Max & & \\
\hline Age (year) & $37,1 \pm 7,11$ & $24-57$ & $40,7 \pm 8,63$ & $24-54$ & $34,3 \pm 8,11$ & $20-57$ & $39,8 \pm 9,60$ & $24-56$ & 0,108 & 0,176 \\
\hline Body height (cm) & $174,2 \pm 8,10$ & $160-186$ & $158,8 \pm 5,61$ & $150-170$ & $175,0 \pm 7,00$ & $160-187$ & $163,5 \pm 5,79$ & $154-177$ & 0,729 & 0,901 \\
\hline Body weight (kg) & $79,5 \pm 14,59$ & $44-110$ & $72,5 \pm 14,30$ & $45-104$ & $82,3 \pm 19,00$ & $58-131$ & $73,1 \pm 15,72$ & $45-99$ & 0,805 & 0,640 \\
\hline Waist/Hip ratio & $0,89 \pm 0,07$ & $0,71-1,1$ & $0,86 \pm 0,06$ & $0,76-1,02$ & $0,89 \pm 0,04$ & $0,79-0,96$ & $0,86 \pm 0,08$ & $0,74-1,04$ & 0,563 & 0,954 \\
\hline BMI $\left(\mathrm{kg} / \mathrm{m}^{2}\right)$ & $26,1 \pm 4,27$ & $17,2-34,7$ & $28,7 \pm 4,95$ & $17-36,2$ & $26,9 \pm 5,64$ & $19,4-39,2$ & $27,3 \pm 5,68$ & $18-34,9$ & 0,559 & 0,385 \\
\hline Body fat mass (\%) & $21,2 \pm 6,35$ & $7,1-35,3$ & $39,6 \pm 9,90$ & $15-59,8$ & $22,1 \pm 7,10$ & $12,0-36,5$ & $38,3 \pm 14,10$ & $15,5-58,3$ & 0,632 & 0,714 \\
\hline Lean body mass (\%) & $40,6 \pm 3,40$ & $32,4-47,2$ & $29,4 \pm 4,61$ & $19,7-41$ & $40,4 \pm 3,67$ & $33,3-45,8$ & $29,3 \pm 6,53$ & $20,5-41,0$ & 0,904 & 0,972 \\
\hline Total body water (\%) & $54,1 \pm 4,31$ & $44,4-63,8$ & $41,7 \pm 7,00$ & $27,6-58,4$ & $53,4 \pm 4,91$ & $43,6-60,5$ & $42,9 \pm 9,62$ & $28,6-58,3$ & 0,588 & 0,797 \\
\hline Bone mass (kg) & $14,3 \pm 1,31$ & $12,5-18$ & $10,6 \pm 1,21$ & $7,6-13,7$ & $14,1 \pm 1,63$ & $12,0-15,9$ & $10,6 \pm 0,90$ & $9,1-12,8$ & 0,536 & 0,951 \\
\hline
\end{tabular}

$\mathrm{p}^{1}:{ }^{*} \mathrm{p}<0,05$, Independent $\mathrm{t}$ test (male subjects were compared between.)

$\mathrm{p}^{2}:{ }^{*} \mathrm{p}<0,05$, Independent $\mathrm{t}$ test (female subjects were compared between.).

Table 3. Daily mean energy and nutrients intake

\begin{tabular}{|c|c|c|c|c|c|c|}
\hline \multirow{3}{*}{ Energy and Nutrients } & \multicolumn{2}{|c|}{ Men (n: 49) } & \multicolumn{4}{|c|}{ Women (n: 47) } \\
\hline & Anti-TNF (+) & Anti-TNF (-) & & Anti-TNF (+) & Anti-TNF (-) & \\
\hline & $\bar{x} \pm \mathrm{SD}$ & $\bar{x} \pm \mathrm{SD}$ & $\mathbf{p}$ & $\bar{x} \pm \mathrm{SD}$ & $\bar{x} \pm \mathrm{SD}$ & $\mathbf{p}$ \\
\hline Energy (kcal) & $2399,9 \pm 657,41$ & $2069,8 \pm 362,16$ & $0,036 *$ & $2102,2 \pm 503,38$ & $1659,1 \pm 277,11$ & $0,001 *$ \\
\hline CHO (g) & $302,4 \pm 125,26$ & $249,1 \pm 72,95$ & 0,076 & $242,8 \pm 102,36$ & $186,1 \pm 55,63$ & $0,022 *$ \\
\hline CHO (\%) & $49,7 \pm 8,31$ & $48,9 \pm 8,88$ & 0,733 & $45,8 \pm 11,07$ & $45,8 \pm 10,20$ & 0,987 \\
\hline Protein (g) & $95,1 \pm 27,45$ & $88,7 \pm 19,6$ & 0,360 & $77,7 \pm 22,39$ & $66,5 \pm 15,24$ & 0,05 \\
\hline Protein (\%) & $16,4 \pm 4,02$ & $17,4 \pm 2,87$ & 0,296 & $15,1 \pm 3,15$ & $16,5 \pm 3,10$ & 0,141 \\
\hline Fat (g) & $87,7 \pm 18,61$ & $77,4 \pm 23,20$ & 0,093 & $90,1 \pm 22,73$ & $70,1 \pm 24,20$ & $0,005^{*}$ \\
\hline Fat (\%) & $33,8 \pm 7,50$ & $33,4 \pm 8,84$ & 0,871 & $38,9 \pm 9,70$ & $37,7 \pm 10,51$ & 0,685 \\
\hline SFA (g) & $32,8 \pm 9,06$ & $29,1 \pm 8,96$ & 0,154 & $34,6 \pm 9,18$ & $26,6 \pm 9,29$ & $0,005^{*}$ \\
\hline MUFA (g) & $36,0 \pm 8,51$ & $29,5 \pm 9,69$ & $0,017^{*}$ & $36,1 \pm 10,63$ & $26,8 \pm 10,70$ & $0,005^{*}$ \\
\hline Cholesterol (mg) & $330,7 \pm 162,18$ & $311,4 \pm 164,70$ & 0,680 & $322,3 \pm 145,35$ & $255,4 \pm 149,47$ & 0,127 \\
\hline w-3 (g) & $1,5 \pm 0,65$ & $1,5 \pm 0,77$ & 0,865 & $1,7 \pm 0,72$ & $1,4 \pm 0,72$ & 0,107 \\
\hline w-6 (g) & $10,6 \pm 4,59$ & $11,4 \pm 6,10$ & 0,586 & $11,8 \pm 5,80$ & $10,2 \pm 6,23$ & 0,387 \\
\hline$w-6 / w-3$ & $7,3 \pm 4,12$ & $8,5 \pm 4,82$ & 0,389 & $7,4 \pm 4,19$ & $9,2 \pm 9,75$ & 0,440 \\
\hline Fibre (g) & $28,3 \pm 11,17$ & $21,5 \pm 7,50$ & $0,016^{*}$ & $26,5 \pm 11,71$ & $18,3 \pm 6,68$ & $0,005^{*}$ \\
\hline
\end{tabular}

${ }^{*} \mathrm{p}<0,05$, Independent $\mathrm{t}$ test. 
Table 4. Serum leptin's correlation with anthropometric measurements

\begin{tabular}{|c|c|c|c|c|c|c|c|c|}
\hline & \multicolumn{4}{|c|}{ Anti-TNF (+) } & \multicolumn{4}{|c|}{ Anti-TNF (-) } \\
\hline & \multicolumn{2}{|c|}{ Men (n: 25) } & \multicolumn{2}{|c|}{ Women (n: 23) } & \multicolumn{2}{|c|}{ Men (n: 24) } & \multicolumn{2}{|c|}{ Women (n: 24) } \\
\hline & $\mathrm{r}$ & $\mathrm{p}$ & $\mathrm{r}$ & $\mathrm{p}$ & $\mathrm{r}$ & $\mathrm{p}$ & $\mathrm{r}$ & $\mathrm{p}$ \\
\hline BMI $\left(\mathrm{kg} / \mathrm{m}^{2}\right)$ & 0,655 & $0,002 *$ & 0,548 & $0,010^{*}$ & 0,807 & $0,001^{*}$ & 0,618 & $0,004^{*}$ \\
\hline Waist/Hip ratio & 0,334 & 0,149 & 0,465 & $0,034^{*}$ & 0,661 & $0,001^{*}$ & 0,373 & 0,105 \\
\hline Body fat mass (\%) & 0,553 & $0,011^{*}$ & 0,444 & $0,44^{*}$ & 0,743 & $0,001 *$ & 0,597 & $0,001^{*}$ \\
\hline Lean body mass (\%) & $-0,558$ & $0,011^{*}$ & $-0,282$ & 0,216 & $-0,728$ & $0,001^{*}$ & $-0,526$ & $0,017^{*}$ \\
\hline Total body water (\%) & $-0,494$ & $0,027^{*}$ & $-0,482$ & $0,027 *$ & $-0,742$ & $0,001^{*}$ & $-0,615$ & $0,004^{*}$ \\
\hline Bone mass (kg) & $-0,450$ & $0,046 *$ & $-0,240$ & 0,295 & $-0,682$ & $0,001^{*}$ & $-0,693$ & $0,027 *$ \\
\hline
\end{tabular}

${ }^{*} \mathrm{p}<0,05$, Pearson correlation test.

\section{Discussion}

The present study examined differences in dietary assessment, serum leptin levels and several anthropometric measurements between AS patients receiving anti TNF- $\alpha$ or NSAID treatment. To demonstrate this difference, we focused on the effect of anti TNF- $\alpha$ therapy to serum leptin levels and dietary intake, which biological therapy may change dietary intake by suppressing the serum leptin levels. Daily average of energy, fibre and monounsaturated fatty acids (MUFAs) intake were significantly higher in patients receiving anti TNF- $\alpha$ treatment. Further more women receiving treatment with anti TNF- $\alpha$ had considerably higher saturated fat, total fat (g), and total CHO (g) intake. Nutritional statuses during inflammation in rheumatologic diseases have been conducted in a few studies. One of the studies showed that dietary intakes of MUFA and fish oil correlated with the suppression of the inflammatory status. In contrast, larger intakes of w-6/w-3 and saturated fatty acid correlated to promoted inflammatory status [18]. In another study, both men and women with active rheumatoid arthritis ingested significantly less energy from CHO and more energy from fat. Women ingested significantly higher amount of saturated fat and MUFA than the recommended dietary allowance (RDA). Both groups took less in fibre [19]. In our study we found significant difference in dietary intake between AS patients receiving anti TNF- $\alpha$ or NSAID treatment, however no correlations were found between serum leptin levels. Likewise, in another study no major changes were observed for serum leptin and total adiponectin levels in RA and AS patients receiving TNF- $\alpha$ inhibitors [20]. Although some previous animal studies have suggested that TNF- $\alpha$ and IL-1B $[9,21]$ correlates with serum leptin levels, further human studies is necessary to verify this association in AS.

Moreover, in our study there were positive correlations between the serum leptin concentration, BMI and body fat mass (\%), which are consistent with previous reports. However, no significant difference in serum leptin levels was found between AS patients receiving anti TNF- $\alpha$ or NSAID treatment. In contrast, to this a study has been reported that the long-term in vitro stimulation of adipose tissue by TNF- $\alpha$ or interleukin- $1 \beta$ inhibits leptin and leptin mRNA production [22]. However in this study, women patients significantly had higher serum leptin levels compared to men. This result generally attributed to a higher relative fat mass in women $[23,24]$ as also shown in this study (Table 2). In our study AS patients'-both men and women- mean BMI and body fat mass (\%) were higher than the WHO health criteria. It has been found that obesity represents a risk factor for a poor remission rate in RA patients treated with anti TNF- $\alpha$ agents [25]. And also optimizing the nutritional status influences the therapeutic effect of anti TNF- $\alpha$ [26]. A personalized nutritional treatment plan might be a good option for an effective results in AS. Accordingly, the mechanism of TNF- $\alpha$ inhibitors serum leptin and dietary intake requires further investigation in AS.

\section{Conclusion}

Overall, our results suggested that anti TNF- $\alpha$ treatment might affect dietary intake. However we have found no correlation between the treatment and serum leptin levels. Moreover AS patients mean BMI is higher than recommended and high BMI is a risk factor for recovery and related with nutritional status and physical activity. Besides that increase in food intake can be leading factor to weight gain, which may affect the recovery of the rheumatologic diseases. Recommended nutrition intake together with drug therapy may lead to more effective treatment. In further studies, we recommend a comprehensive nutritional assessment and intervention prior to treatments.

\section{References}

[1] Sieper J. Developments in the scientific and clinical understanding of the spondyloarthritides. Arthritis Res Ther 2009; 11:208.

[2] Ghasemi-rad, M., Attaya, H., and Lesha, E. (2015). Ankylosing spondylitis: A state of the art factual backbone.World Journal Radiology, 7(9), 236-252.

[3] Crew MD, Effros RB, Walford RL, Zeller E,Cheroutre H, Brahn E. Transgenic mice expressing a truncated Peromyscus leucopus TNF-alpha gene menifest an arthritis resembling ankylosing spondylitis. J Interferon Cytokine Res1998; 18: 219-225.

[4] Van der Heijde, D., Landewe', R., Baraliakos, X., Houben, H., van Tubergen, A., and Williamson, P. (2008). Radiographic findings following two years of infliximab therapy in patients with ankylosing spondylitis. Arthritis Rheumatology, 58(10), 3063-70.

[5] Spiegelmen BM, Flier JS 2001 Obesity and the regulation of energy balance. Cell 104:531-543.

[6] Hekimoglu, A. (2006). Leptin ve fizyopatolojik olaylardaki rolü. Dicle Tip Dergisi, 33(4), 259-267.

[7] Shen J, Sakaida I, Uchida K, Terai S, Okita K. Leptin enhances TNF- $\alpha$ production via p38 and JNK MAPK in LPS-stimulated Kupffer cells. Life Sci. 2005; 77: 1502-15. 
[8] Sarraf P, Frederich RC, Turner EM, Ma G, Jaskowiak NT, Rivet DJ 3rd et al. Multiple cytokines and acute inflammation raise mouse leptin levels: potential role in inflammatory anorexia. J Exp Med 1997; 185: 171-175.

[9] Lukuni N, Lai Kwan Lam Q, Lu L, Matarese G, La Cava A. Leptin and inflammation. Curr Immunol Rev. 2008 May 1; 4(2): 70-79.

[10] Gaetke LM, Oz HS, Frederich RC, and McClain CJ. Anti TNFalpha antibody normalizes serum leptin in IL-2 deficient mice. J. Am Coll Nutr. 2003 Oct; 22(5): 415-20.

[11] Zumbach M S, Boehme M W, Wahl P, Stremmel W, Ziegler R, Nawroth P P. Tumor necrosis factor increases serum leptin levels in humans. J Clin Endocrinol Metab 1997 824080-4082.4082.

[12] Rakıcıoğlu, N., Tek Acar, N., Ayaz, A., and Pekcan, G. (2006). Besin ve Yemek Fotografları Katalogu. Ankara: Ata Ofset Matbaacilık.

[13] BeBis (Beslenme Bilgi Sistemi) bilgisayar yazılım program versiyon 7.

[14] Pekcan, G., Sanlıer, N., ve Bas, M. (2015). Türkiye Beslenme Rehberi (TÜBER). T.C. Sağlık Bakanlığı, Ankara.

[15] Weber, J L. (2003). Height and Weight Measurement Procedures. Training Menual Originally Developed by BMI Task Force.

[16] Waist Circumference and Waist-Hip Ratio Report of a WHO Expert Consultation. (2008). Geneva.

[17] Guidelines for Data Processing and Analysis of the International Physical Activity Questionnaire (IPAQ) - (2004). Short Form.

[18] Hayashi, H., Satoi, K., and Sato Mito, N. (2012). Nutritional status in relation to adipokines and oxidative stress is associated with disease activity in patients with rheumatoid arthritis. Nutrition, 28, 1109-1114.
[19] Kremer, J M., and Bigaouette, J. (1996). Nutrient intake of patients with rheumatoid arthritis is deficient in pyridoxine, zinc, copper, and magnesium. Journal of Rheumatology, 23(6), 990-4.

[20] Toussirot, E., Mourot, L., and Dehecq, B. (2014). Dumoulin, $\mathrm{TNF} \alpha$ blockade for inflammatory rheumatic diseases is associated with a significant gain in android fat mass and has varying effects on adipokines: a 2-year prospective study. European Journal of Nutrition, 53(3), 951-961.

[21] Paquet, J., Goebel, J C., Delaunay, C., and Pinzano, A. (2012). Cytokines profiling by multiplex analysis in experimental arthritis: which pathophysiological relevance for articular versus systemic mediators? Arthritis Research Theory, 14(2), 60.

[22] Brunn, J.M., Pedersen S.B., Kristensen K., and Richelsen B. Effects of pro-inflammatory cytokines and chemokines on leptin production in human adipose tissue in vitro. Mol Cell Endocrinol, 190 (2002), pp. 91-99.

[23] Maffei M, Halaas JL, Ravussin E, et al: Leptin levels in human and rodent: Measurement of plasma leptin and ob RNA in obese and weight-reduced subjects. Nat Med 1:1155-1161, 1995

[24] Considine RV, Sinha MK, Heiman ML, et al: Serum immunoreactive-leptin concentrations in normal-weight and obese humans. N Engl J Med 334:292-295, 1996

[25] Gremese, E., and Carletto, A. (2013). Obesity and reduction of the response rate to anti-tumor necrosis factor $\alpha$ in rheumatoid arthritis: an approach to a personalized medicine. Arthritis Care and Research, 65(1), 94-100.

[26] Sumi, R., and Nakajima, K. (2015). Influence of nutritional status on the therapeutic effect of infliximab in patients with Crohn's disease. Surgery today (Epub ahead of print). 